Notes: The authors declare no conflict of interest.

\title{
In vitro versus in vivo protein digestibility techniques for calculating PDCAAS (protein digestibility-corrected amino acid score) applied to chickpea fractions
}

\author{
Olga Luisa Tavano ${ }^{\mathrm{a}, *}$, Valdir Augusto Neves ${ }^{\mathrm{b}}$, Sinézio Inácio da Silva Júnior ${ }^{\mathrm{c}}$ \\ a Federal University of Alfenas, Nutrition Faculty, 700 Gabriel Monteiro da Silva St, Alfenas, MG 37130-000, Brazil

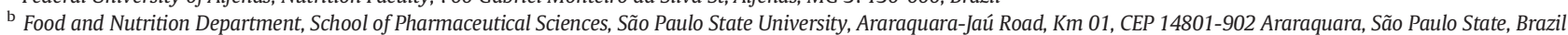 \\ c Food and Medicines Department, School of Pharmaceutical Sciences, Federal University of Alfenas, Gabriel Monteiro da Silva Street, 700, CEP: 37130-000, Alfenas, Minas Gerais State, Brazil
}

\section{A R T I C L E I N F O}

\section{Article history:}

Received 22 August 2016

Received in revised form 4 October 2016

Accepted 5 October 2016

Available online 6 October 2016

\section{Keywords:}

Protein digestibility

In vitro digestibility

PDCAAS

Chickpea

Protein fractions

\begin{abstract}
A B S T R A C T
Seven different in vitro methods to determine the protein digestibility for chickpea proteins were considered and also the application of these methodologies for calculating PDCAAS (protein digestibility-corrected amino acid score), seeking their correlations with the in vivo methodology. In vitro digestibility of raw and heated samples were determined using pepsin-pancreatin hydrolysis, considering soluble nitrogen via Kjeldahl ( $\mathrm{ppKJ}$ ) and hydrolysed peptide linkages using trinitrobenzenesulfonic acid and o-phthaldialdehyde. In vitro digestibility was also determined using trypsin, chymotrypsin and peptidase (3-Enz) or trypsin, chymotrypsin, peptidase and pronase solution (4-Enz). None of the correlations between in vitro and in vivo digestibilities were significant (at $p<0.0500$ ), but, strong correlations were observed between PDCAAS calculated by in vitro and in vivo results. PDCAAS-ppKJ, PDCAAS-3-Enz and PDCAAS-4-Enz presented the highest correlations with in vivo method, $\mathrm{r}=$ $0.9316,0.9442$ and $0.9649(p<0.0500)$, respectively. The use of in vitro methods for calculating PDCAAS may be promising and deserves more discussions.
\end{abstract}

(c) 2016 Elsevier Ltd. All rights reserved.

\section{Introduction}

Dietary protein quality is measured using a variety of methods, many of which are related to animal responses (often rats) after feeding them the test protein. These methods have the advantage of reflecting both the supply of essential amino acids and the digestibility of the protein, which are two important factors in protein evaluation. For dietary proteins to meet indispensable amino acid demands, their potential digestibility must be considered (Boye, Wijesinha-Bettoni, \& Burlingame, 2012).

Although growth tests using rats have been used for many years (PER-Protein Efficiency Ratio, NPR-Net Protein Ratio, or NPU-Net Protein Utilization), these tests suffer from the disadvantage that rats may exhibit different amino acid requirements than humans. In this sense, nitrogen balance assays in rats, such as digestibility evaluation, may provide results that are the more directly relevant to humans (Schaafsma, 2012).

In 1989, the FAO/WHO Expert Consultation on Protein Quality Evaluation recommended the use of the Protein Digestibility Corrected

\footnotetext{
* Corresponding Author.

E-mail address: tavanool@yahoo.com.br (O.L. Tavano).
}

Amino Acid Score (PDCAAS) method, which considers both the indispensable amino acid content of the test protein and its digestibility. In this framework, amino acid score $=$ content of the first limiting amino acid in the test protein/corresponding content of this amino acid in the WHO/FAO/UNU reference pattern (preschool child requirements, $\mathrm{mg} / \mathrm{g}$ ), and PDCAAS $=$ protein digestibility $\times$ amino acid score. This is an extremely important measure, despite recent criticism and constant revision (Schaafsma, 2012; Boye et al., 2012; Leser, 2013; WHO/FAO/UNU, 2007).

Ileal digestibility is most appropriate for quantifying digestion, because true fecal nitrogen digestibility does not account for essential amino acids that are lost into the colon via intestinal flora activity (Schaafsma, 2012). However, rat assays for true digestibility have instead been extensively used, in part because of their practicality compared to the use of ileal-fistulated pigs. On the other hand, in vivo experiments suffer from high costs and long experimental run times (approximately 9 days at minimum) (McDonough et al., 1990), as well as ethical objections to animal use (Schaafsma, 2012). Thus, the employment of in vitro alternative methodologies must be considered and further developed to improve correlations with in vivo assays.

Although some studies have already PDCAAS data calculated with the use of in vitro digestibility values, a large number of in vitro methods 
can be found in the literature. The purpose of this study was to compare protein digestibility measurements for chickpea proteins using a variety of in vitro methods and to use these methodologies to compute PDCAAS while evaluating them as potential substitutes for in vivo procedures, contributing to the choice of a methodology that, once adopted by different authors, facilitate comparison of data and well express what would be obtained by in vivo assays.

Chickpeas protein fractions were chosen as the basis for discussions on the comparison between in vitro and in vivo methodologies because these samples had previously been studied in our laboratory and their nutritional values have been well characterized using different in vivo and antinutritional assays (Tavano, Silva Junior, Demonte, \& Neves, $2008,2005)$. This gives a clearer picture and context for the results. The in vitro protein digestibility methods employed in this study are based on the measurement of potential susceptibility of protein peptide bonds to proteolysis by digestive enzymes, which is one of the first characteristics of proteins that interferes with the real process of in vivo protein digestion, and therefore in their nutritional value. These assays used enzyme mixtures or different enzymes sequences for proteolysis of protein sample, which try to mimic the effects of the human digestion process. We highlight the methods of Akeson and Stahman (1964) and Hsu, Vavak, Satterlee, and Miller (1977). The first is an ordered enzyme method, where pepsin is the first enzyme applied followed by pancreatin action, which hydrolysis effectiveness calculations were based on the following principles: the quantification of soluble nitrogen in the presence of a precipitation agent compared to the total nitrogen of the sample (e.g., the $\mathrm{ppKj}$ ), because increased hydrolysis leads to greater solubility of protein fragments; or quantification of cleaved peptide bonds calculated by determining the free amino groups released through the reaction of compounds that react with amino groups using TNBS (trinitrobenzenesulfonic acid) or OPA (o-phthaldialdehyde) reactions. The second consists of a multienzyme mix system (trypsin, chymotrypsin, and peptidase) with determination of protein sample $\mathrm{pH}$ before and after 10 min of reaction, which monitors the $\mathrm{H}^{+}$ions released by broken peptide bonds and free carboxyl group "generation" (pH-drop assays). This second method is quick and simple to apply. In addition, another titrimetric method was used, including an additional step of hydrolysis by using pronase. In this way, besides the issues related to the procedure itself (which mainly involve enzyme choice), the adopted principle in each hydrolysis measurement method can influence the results of in vitro protein digestion assays and should be carefully considered as discussed in this paper.

\section{Materials and methods}

\subsection{Materials}

Chickpea seeds (Cicer arietinum L.) cv. IAC-Marrocos, were cultivated by and obtained from the Instituto Agronômico de Campinas, São Paulo, Brazil. Chickpea defatted flour and its protein fractions were obtained as previously described (Tavano et al., 2008), using differential protein solubility in different solvents (defatted flour, albumins, total and major globulins, and glutelins presenting 25.01, 75, 91.2, 97.3, and $68.6 \mathrm{~g} /$ $100 \mathrm{~g}$ of protein, respectively). Pepsin (from porcine gastric mucosa), trypsin (porcine, Type IX), chymotrypsin (Type II), peptidase (from porcine intestinal mucosa), pancreatin, pronase (bacterial protease from Streptomyces griseus, Type XIV), 2,4,6-trinitrobenzene sulfonic acid (TNBS), o-phthaldialdehyde (OPA) and benzoyl-DL-arginine-pnitroanilide (BapNa) were purchased from Sigma Chemical Co., St. Louis, MO. Others chemicals were reagent grade.

\subsection{Heat treatment}

A portion of defatted flour and protein fractions were suspended in distilled water $(1: 6 \mathrm{w} / \mathrm{v})$, autoclaved at $121^{\circ} \mathrm{C}$ for $15 \mathrm{~min}$, and immediately cooled and lyophilized again, as described by Tavano et al. (2008).

\subsection{Nitrogen determination}

Nitrogen was determined using the Kjeldahl method (AOAC, 1990). Crude protein was calculated as $\mathrm{N} \times 6.25$ for chickpea proteins and $\mathrm{N} \times 6.38$ for casein samples.

\subsection{Pepsin/pancreatin method}

In vitro protein digestibility of $50 \mathrm{mg}$ protein from raw and heated samples were determined as described by Akeson and Stahman (1964) using a pepsin-pancreatin (pp) incubation sequence $(0.75 \mathrm{mg}$ pepsin, 1.641 units, and $2.0 \mathrm{mg}$ pancreatin), at $37^{\circ} \mathrm{C}$, for $3 \mathrm{~h}$ and $24 \mathrm{~h}$, respectively. The enzymatic reaction was then interrupted by adding $10 \%$ trichloroacetic acid, followed by centrifugation at $7000 \mathrm{~g}$ for $15 \mathrm{~min}$. The resulting supernatant was used for determining the degree of hydrolysis using the following methods:

\subsection{1. $p p K j$}

Determination of soluble nitrogen by Kjeldahl (AOAC, 1990). Percent hydrolysis was calculated as the percent of soluble nitrogen compared to the total nitrogen in the sample and using the following ratio:

$\%$ Hydrolysis $=\left(\mathrm{N}_{\mathrm{a}}-\mathrm{N}_{\mathrm{ba}}-\mathrm{N}_{\mathrm{be}}\right) / \mathrm{N}_{\mathrm{t}} \times 100$, where: $\mathrm{N}_{\mathrm{a}}=$ soluble nitrogen in the supernatant of the hydrolysed sample; $\mathrm{N}_{\mathrm{ba}}=$ soluble nitrogen in the supernatant of the non-hydrolysed sample (a blank sample without enzymes); $\mathrm{N}_{\text {be }}=$ soluble nitrogen in the supernatant of solution containing only enzyme (a blank sample without samples); $\mathrm{N}_{\mathrm{t}}=$ total nitrogen in the sample.

2.4.2. Determination of the percent of peptide linkages hydrolysed, as determined by the number of free amino groups in the supernatant. This was calculated using the following methods:

2.4.2.1. ppTNBS. Free amino groups in the supernatant were determined using trinitrobenzenesulfonic acid (TNBS), as described by Fields (1972) and modified by Spadaro, Draghetta, Del Lama, Camargo, and Greene (1979). The mixture contained the following: 0 to $0.4 \mathrm{~mL}$ of sample, $0.4 \mathrm{~mL}$ borate $/ \mathrm{KOH}$ buffer, $\mathrm{pH} 9.5$ and $0.2 \mathrm{~mL}$ of TNBS solution ( $5 \mathrm{mM}$ ). After $50 \mathrm{~min}$ at $25^{\circ} \mathrm{C}$, the reaction was interrupted by addition of $0.2 \mathrm{~mL}$ of $18 \mathrm{mM}$ sodium sulfite in $2 \mathrm{M}$ sodium phosphate buffer, and the absorbance was measured at $420 \mathrm{~nm}$ using the reagent solution as a blank.

2.4.2.2. $p$ POPA. Free amino groups in the supernatant were measured using o-phthaldialdehyde (OPA), as described by Church, Swaisgood, Porter, and Catignani (1983). Aliquots of samples between 0 and $130 \mu \mathrm{L}$ were combined with $1 \mathrm{~mL}$ of OPA reagent that was freshly prepared every day ( $25 \mathrm{~mL}$ of $100 \mathrm{nM}$ sodium tetraborate, $2.5 \mathrm{~mL}$ SDS $20 \%, 40 \mathrm{mg}$ OPA $/ \mathrm{mL}$ methanol, $100 \mu \mathrm{L} \beta$-mercaptoethanol and adjusted to $50 \mathrm{~mL}$ with distilled water). After 2 min of reaction the absorbance was measured at $340 \mathrm{~nm}$ using the reagent solution as a blank.

Analytical reference curves for both ppTNBS and PpOPA were constructed using L-leucine as a standard. The total moles of amino acids present in the initial mass of protein were estimated using the average molecular weight of amino acids (MW = 113) and also via corrected values with respect to the individual real concentration values in the sample and molecular weights of each amino acid considering the previously determined sample aminograms (Tavano et al., 2008). The equation used to calculate percent hydrolysis $(\% \mathrm{H})$ was:

$\% \mathrm{H}=($ AAs - AAba-Aabe $) \times 100 /$ Aatm or Aatc, where: AAs $=$ amino acid mols in the sample supernatant; AAba = amino acid mols in the blank supernatant of the samples; AAbe = amino acid mols in the blank supernatant of the enzymes; AAtm = total amino acid mols in the sample considering the mean molecular weight of the amino acids ( $p$ POPA and ppTNBS); AAtc = total amino acid mols in the sample considering the individual molecular weight of each amino acid ( $p$ OPAc and ppTNBSc). 


\subsection{3-Enzyme method (3-Enz)}

In vitro protein digestibility (IVPD) was applied to unheated and heated chickpea protein samples using the multienzyme method as described by Hsu et al. (1977). Protein was dispersed in $10 \mathrm{~mL}$ distilled water $\left(6.25 \mathrm{mg} \mathrm{mL}^{-1}\right)$ and adjusted to $\mathrm{pH} 8.0$ at $37^{\circ} \mathrm{C}$ in a water bath followed by addition of $1.0 \mathrm{~mL}$ multienzyme solution (1.6 mg trypsin, 24.320 units, $3.1 \mathrm{mg}$ chymotrypsin, 155 units and $1.3 \mathrm{mg}$ of peptidase from porcine intestinal mucosa, 0.133 units $\mathrm{ml}^{-1}$ ). The $\mathrm{pH}$ variation was then recorded after $10 \mathrm{~min}$ reaction. The equation $\mathrm{Y}=210.46-$ $18.10 \mathrm{X}$, was used for calculating in vitro digestibility, where $\mathrm{X}$ is $\mathrm{pH}$ change after $10 \mathrm{~min}$ (Hsu et al., 1977).

\subsection{4-Enzyme method (4-Enz)}

The AOAC-982.30 (Association of Official Analytical Chemists, 2000) method was then applied to the unheated and heated chickpea protein samples. Protein was dispersed in water $(6.25 \mathrm{mg}$ nitrogen or $62.5 \mathrm{mg}$ protein in $10 \mathrm{~mL}$ distilled water) and adjusted to $\mathrm{pH} 8.0$ at $37^{\circ} \mathrm{C}$ in a water bath. Multienzyme solution A (22.704 units of trypsin, 182 units chymotrypsin and 0.052 units of peptidase from porcine intestinal mucosa, in $1.0 \mathrm{~mL}$ ) was added. After exactly $10 \mathrm{~min}$ at $37^{\circ} \mathrm{C}, 1.0 \mathrm{~mL}$ of enzyme solution B (6.5 units of pronase in $1.0 \mathrm{~mL}$ distilled water) was added, and the sample was incubated for an additional $20 \mathrm{~min}$ at $55^{\circ} \mathrm{C}$. The equation $\mathrm{Y}=234.84-22.56 \mathrm{X}$, was used for calculating in vitro digestibility, where $\mathrm{X}$ is the $\mathrm{pH}$ value after the final $20 \mathrm{~min}$.

\subsection{Protein Digestibility Corrected Amino Acid Scoring}

Protein Digestibility Corrected Amino Acid Scoring (PDCAAS) was calculated on the basis of the WHO/FAO/UNU essential amino acid scoring pattern for 1- to 2-year-old children (WHO/FAO/UNU, 2007), as described by Sarwar and Mcdonough (1990), using the protein digestibility values obtained via in vitro or in vivo methods for correction. PDCAAS = (limiting amino acid content in sample protein/same amino acid content of the reference pattern $) \times$ protein digestibility.
When in vivo true protein digestibility was used in calculations, the previously obtained results (Tavano et al., 2008) were considered.

\subsection{Statistical analyses}

All assays were performed in triplicate and are expressed as means \pm SD. Analysis of variance (ANOVA) was used to compare results $(p \leq 0.05)$ using Student's $t$-test. Statistical analysis was conducted using Statsoft STATISTICA 8.0 (Statsoft, 2007).

\section{Results and discussion}

Results of pepsin-pancreatin hydrolysis assays varied widely between the different methods of determining the degree of hydrolysis (ranging from 34.73 to $64.49 \%$ for unheated flour, for instance), as shown in Table 1 . The ppKj method (pepsin-pancreatin hydrolysis followed by Kjeldahl determination of soluble nitrogen) was not able to detect the improvement in digestibility of heated samples, while most other in vitro methods could detect such differences. Although ppTNBS (pepsin-pancreatin hydrolysis followed by TNBS amino group determination), ppOPA (pepsin-pancreatin hydrolysis followed by OPA amino group determination) and ppKj are based on the same sample hydrolysate (pepsin-pancreatin hydrolysates stopped via TCA precipitation), different interpretations of the products generated may arise because $\mathrm{ppKj}$ is not capable of differentiating whether nitrogen is from peptides or free amino acids. In other words, ppKj can confuse one tetrapeptide for four free amino acids. This does not occur using pPOPA and ppTNBS, e.g., a tetrapeptide released by hydrolysis that remains in solution will be recognized as a single $\alpha$-amino group released (one broken link), while using the ppKjeldahl method this same fragment is interpreted as four nitrogens in solution, even if only one peptide bond has been broken. This explains the high hydrolysis values for most samples using this method compared to data generated by ppOPA and ppTNBS (Table 1).

While this observation may suggest that $\mathrm{ppKj}$ overestimates digestibility, it is important to consider that for in vivo assays (true digestibility via fecal rat assays), protein digestibility is evaluated considering the

Table 1

In vitro and in vivo chickpea protein digestibility of chickpea flour and fractions using different methodologies.

\begin{tabular}{|c|c|c|c|c|c|c|c|c|}
\hline \multirow[t]{2}{*}{ Samples ${ }^{\mathrm{a}}$} & \multicolumn{7}{|c|}{ In vitro methods ${ }^{\mathrm{b}}$ (\% hydrolysis degree) } & \multirow[t]{2}{*}{ In vivo ${ }^{\mathrm{C}}(\mathrm{TD})$} \\
\hline & ppOPA & ppOPAc & ppTNBS & ppTNBSc & $\mathrm{ppKj}$ & 3-Enz & 4-Enz & \\
\hline \multirow[t]{2}{*}{ Casein } & $65.99^{\mathrm{aA}}$ & $88.41^{\mathrm{B}}$ & $47.04^{\mathrm{a}}$ & $63.02^{\mathrm{A}}$ & $87.09^{\mathrm{B}}$ & $86.05^{\mathrm{aB}}$ & 107.75 & $96.08^{\mathrm{a}}$ \\
\hline & \pm 2.90 & \pm 3.88 & \pm 1.17 & \pm 1.57 & \pm 4.09 & \pm 0.55 & \pm 1.84 & \pm 1.61 \\
\hline \multirow[t]{2}{*}{ Flour (U) } & $42.20^{\mathrm{bA}}$ & 48.91 & $34.73^{\mathrm{b}}$ & $40.25^{\mathrm{aA}}$ & $64.49^{\mathrm{a}}$ & $70.99^{\mathrm{B}}$ & $80.53^{C}$ & $78.42^{\mathrm{bBC}}$ \\
\hline & \pm 1.19 & \pm 1.38 & \pm 0.99 & \pm 1.15 & \pm 3.42 & \pm 0.27 & \pm 0.60 & \pm 7.88 \\
\hline \multirow[t]{2}{*}{ Flour $(\mathrm{H})$} & $53.00^{\text {defA }}$ & $61.42^{\mathrm{acd} A B}$ & $38.05^{\mathrm{bc}}$ & $44.10^{\mathrm{ab}}$ & $63.59^{\mathrm{aB}}$ & $80.26^{\mathrm{aC}}$ & $82.03^{\mathrm{aD}}$ & $78.75^{\mathrm{bCD}}$ \\
\hline & \pm 4.76 & \pm 5.52 & \pm 2.13 & \pm 2.47 & \pm 3.17 & \pm 0.58 & \pm 0.34 & \pm 3.42 \\
\hline \multirow[t]{2}{*}{ Albumin (U) } & $40.10^{\mathrm{cA}}$ & $45.64^{\mathrm{b}}$ & 27.64 & 31.46 & $57,28^{\mathrm{bc}}$ & 68.19 & 78.08 & $88.76^{c}$ \\
\hline & \pm 0.88 & \pm 1.01 & \pm 0.43 & \pm 0.49 & $\pm 1,25$ & \pm 0.36 & \pm 0.85 & \pm 4.57 \\
\hline \multirow[t]{2}{*}{ Albumin $(\mathrm{H})$} & $51.01^{\mathrm{dA}}$ & $58.06^{\mathrm{aB}}$ & $39.36^{c}$ & $44.80^{\mathrm{b}}$ & $54,38^{\text {сAB }}$ & 76.37 & $81.96^{\mathrm{a}}$ & $93.00^{\mathrm{a}}$ \\
\hline & \pm 0.47 & \pm 0.53 & \pm 0.65 & \pm 0.74 & \pm 3.70 & \pm 0.29 & \pm 0.34 & \pm 5.04 \\
\hline \multirow[t]{2}{*}{ Total globulin (U) } & $47.51^{\mathrm{e}}$ & $55.66^{c}$ & 31.17 & 36.52 & $75,22^{\mathrm{dA}}$ & $80.68^{\mathrm{aA}}$ & 93.84 & $87.05^{c}$ \\
\hline & \pm 1.33 & \pm 1.56 & \pm 0.22 & \pm 0.25 & \pm 3.26 & \pm 2.26 & \pm 0.60 & \pm 2.46 \\
\hline \multirow[t]{2}{*}{ Total globulin $(\mathrm{H})$} & $68.49^{\mathrm{a}}$ & $80.23^{\mathrm{A}}$ & $47.36^{\mathrm{a}}$ & $55.48^{c}$ & $75.26^{\mathrm{dA}}$ & $88.65^{\mathrm{b}}$ & $96.40^{\mathrm{B}}$ & $94.61^{\mathrm{aB}}$ \\
\hline & \pm 2.04 & \pm 2.39 & \pm 1.33 & \pm 1.56 & \pm 3.95 & \pm 1.01 & \pm 0.47 & \pm 2.17 \\
\hline \multirow[t]{2}{*}{ Major globulin $(\mathrm{H})$} & $61.53^{\mathrm{fA}}$ & $71.86^{\mathrm{dB}}$ & $46.81^{\mathrm{a}}$ & $54.67^{\mathrm{cA}}$ & $70.68^{\mathrm{B}}$ & $89.31^{\mathrm{bC}}$ & $89.63^{\mathrm{bC}}$ & $94.65^{\mathrm{a}}$ \\
\hline & \pm 3.91 & \pm 4.57 & \pm 2.43 & \pm 2.84 & \pm 0.80 & \pm 0.84 & \pm 0.13 & \pm 2.27 \\
\hline \multirow[t]{2}{*}{ Glutelin $(\mathrm{H})$} & $36.56^{\mathrm{cA}}$ & $42.26^{\mathrm{bA}}$ & $37.43^{\mathrm{bcA}}$ & $43.27^{\mathrm{abA}}$ & $59.45^{\mathrm{ab}}$ & 83.52 & 88.72 & $78.19^{\mathrm{b}}$ \\
\hline & \pm 3.84 & \pm 4.43 & \pm 4.53 & \pm 5.23 & \pm 3.40 & \pm 0.21 & \pm 1.07 & \pm 2.01 \\
\hline
\end{tabular}

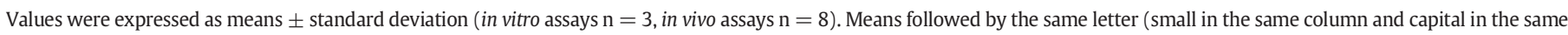
line) indicate no significant difference between samples $(p<0.0500)$.

${ }^{a} \mathrm{U}=$ Unheated sample, $\mathrm{H}=$ heated sample. The heated samples were autoclaving at $121{ }^{\circ} \mathrm{C} / 15 \mathrm{~min}$.

b pPOPA, ppTNBS, ppKj, ppOPAc and ppTNBSc: pepsin/pancreatin hydrolysis method (Akeson \& Stahman, 1964) using o-phthaldialdehyde $\alpha$-amino group detection (OPA),

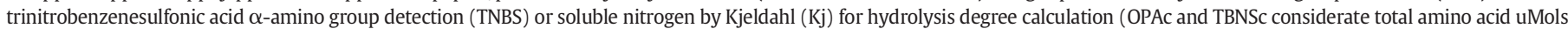

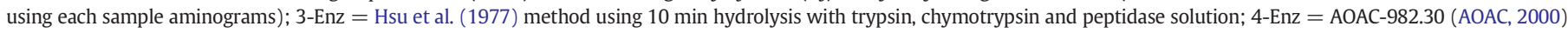
method using 10 min hydrolysis with trypsin, chymotrypsin and peptidase solution, plus additional 10 min using pronase, as described in Materials and methods section.

c $\mathrm{TD}=$ rats fecal true digestibility values, as previously reported in Tavano et al. (2008). 
Table 2

Correlation coefficients between chickpea protein digestibility values obtained using different methods.

\begin{tabular}{|c|c|}
\hline Correlated methods & Correlation coefficients $(r)^{a}$ \\
\hline $\begin{array}{l}\text { Pepsin-pancreatin method } \\
\text { ppOPA/ppTNBS } \\
\text { ppOPAc/ppTNBSc } \\
\text { ppOPA/ppKj } \\
\text { ppOPAc/ppKj } \\
\text { ppTNBS/ppKj } \\
\text { ppTNBSc/ppKj }\end{array}$ & $\begin{array}{l}0.8172(p=0.0132)^{*} \\
0.8289(p=0.0109)^{*} \\
0.6066(p=0.1108) \\
0.6380(p=0.0887) \\
0.3805(p=0.3524) \\
0.4260(p=0.2926)\end{array}$ \\
\hline $\begin{array}{l}\text { 3-Enzymes/pepsin-pancreatin method } \\
\text { 3-Enz/ppOPA } \\
\text { 3-Enz/ppOPAc } \\
\text { 3-Enz/ppTNBS } \\
\text { 3-Enz/ppTNBSc } \\
\text { 3-Enz/ppKj }\end{array}$ & $\begin{array}{l}0.6920(p=0.0572) \\
0.7086(p=0.0491)^{*} \\
0.8233(p=0.0120)^{*} \\
0.8409(p=0.0089)^{*} \\
0.6159(p=0.1039)\end{array}$ \\
\hline $\begin{array}{l}\text { 4-Enzymes/pepsin-pancreatin method } \\
\text { 4-Enz/ppOPA } \\
\text { 4-Enz/ppOPAc } \\
\text { 4-Enz/ppTNBS } \\
\text { 4-Enz/ppTNBSc } \\
\text { 4-Enz/ppKj }\end{array}$ & $\begin{array}{l}0.5544(p=0.1538) \\
0.5804(p=0.1314) \\
0.5240(p=0.1824) \\
0.5558(p=0.1525) \\
0.8132(p=0.0140)^{*}\end{array}$ \\
\hline $\begin{array}{l}\text { 4-Enzymes/3-enzymes method } \\
\text { 3-Enz/4-Enz }\end{array}$ & $0.8275(p=0.0112)^{*}$ \\
\hline $\begin{array}{l}\text { In vivo/in vitro } \\
\text { TD/ppOPA } \\
\text { TD/ppOPAc } \\
\text { TD/ppTNBS } \\
\text { TD/ppTNBSc } \\
\text { TD/ppKj } \\
\text { TD/3-Enz } \\
\text { TD/4-Enz }\end{array}$ & $\begin{array}{l}0.6785(p=0.0640) \\
0.6637(p=0.0727) \\
0.4553(p=0.2570) \\
0.4481(p=0.2654) \\
0.2683(p=0.5205) \\
0.3534(p=0.3904) \\
0.3675(p=0.3704)\end{array}$ \\
\hline
\end{tabular}

a Only chickpea values were considered.

* Marked correlations ( $\mathrm{r}$ ) are significant at $p<0.0500$.

capacity of the protein to be absorbed in the intestinal tract, which is determined through quantification of the ingested nitrogen that is absorbed by the organism. This process is influenced by the hydrolysis susceptibility of the polypeptide chain by digestive enzymes as much as the availability to absorb the generated products. However, this absorption process can occur in the free amino acid form or even in the form of peptides containing few amino acid residues, such as di-, trior tetra peptides, or even more (Pappenheimer, Dahl, Karnovsky, \& Maggio, 1994; Jahan-Mihan, Luhovyy, El Khoury, \& Anderson, 2011). As such, it is important remember that a small number of disrupted peptide bonds should not necessarily be interpreted as a low percentage of absorption or low digestibility in vivo.

On the other hand, it is necessary to observe that in vitro methods that employ soluble nitrogen determination can present additional failures due to limitations in the precipitation process. Yvon, Chabanet, and Pélissier (1989) demonstrated that peptide fragments containing up to fifty residues can stay in solution until $12 \%$ trichloroacetic acid. We could interpret this to mean that any large peptides could be potentially absorbed in the intestine, but it is not clear that this occurs. Although there is evidence to suggest absorption of large peptides such as octapeptides (Pappenheimer et al., 1994), the relationship between the sizes of the soluble proteins in precipitant solutions and peptides that actually can be absorbed merits further study.

Hydrolysis methods that use pPOPA and ppTNBS have another usual inconvenience relative to the final hydrolysis calculation. The $100 \%$ hydrolysis value (total amino acids that would be liberated if all peptide bonds could be cleaved), which is necessary for calculations, may be estimated using the average molecular weight $(\mathrm{PM}=113)$ to calculate the number of total amino acids in the sample, as employed herein (considering the total number of amino acids in $50 \mathrm{mg}$ of test protein), as a simplified protocol for calculation. But, the amino acid profiles of different samples can be very distinct, and considering the large variation between individual molecular weights of the amino acids, the average molecular weight for each protein sample can vary widely. Some authors suggest performing total hydrolysis of a sample (via $\mathrm{HCl} 6 \mathrm{~N}$ hydrolysis) for determining the $100 \%$ equivalent but this step adds more work to the procedure. The ppKjeldahl method does not suffer from this problem, because the initial values of total nitrogen in the samples (100\%) are obtained by the same Kjeldahl methodology used to determine the soluble nitrogen. To verify the influence of the average molecular weight procedure in the final hydrolysis calculations, we compared it with the use of the individual aminogram of each sample as a

Table 3

In vitro and in vivo chickpea protein digestibility expressed as \% of casein results (100\%).

\begin{tabular}{|c|c|c|c|c|c|c|c|c|}
\hline \multirow[t]{2}{*}{ Samples $^{\mathrm{a}}$} & \multicolumn{7}{|c|}{ In vitro methods ${ }^{\mathrm{b}}(\%)$} & \multirow{2}{*}{$\begin{array}{l}\text { In vivo } \\
\% \mathrm{TD}\end{array}$} \\
\hline & ppOPA & OPAC & ppTNBS & ppTNBSc & $\mathrm{ppKj}$ & 3-Enz & 4-Enz & \\
\hline Casein & 100 & 100 & 100 & 100 & 100 & 100 & 100 & 100 \\
\hline \multirow[t]{2}{*}{ Flour (U) } & $63.95^{\mathrm{aeA}}$ & 55.32 & $73.83^{\mathrm{aB}}$ & $63.87^{\mathrm{aA}}$ & $74.05^{\mathrm{aBC}}$ & $82.50^{\mathrm{D}}$ & 69.30 & $83.09^{\mathrm{aCD}}$ \\
\hline & \pm 1.80 & \pm 1.56 & \pm 2.12 & \pm 1.83 & \pm 3.93 & \pm 0.31 & \pm 0.52 & \pm 8.35 \\
\hline \multirow[t]{2}{*}{ Flour $(\mathrm{H})$} & $80.31^{\mathrm{bcdA}}$ & $69.48^{\mathrm{acdB}}$ & $80.89^{\mathrm{abA}}$ & $69.98^{\mathrm{bB}}$ & $73.02^{\mathrm{aAB}}$ & $93.27^{\mathrm{a}}$ & $70.59^{\mathrm{aB}}$ & $83.44^{\mathrm{aA}}$ \\
\hline & \pm 7.22 & \pm 6.25 & \pm 4.53 & \pm 3.92 & \pm 3.64 & \pm 0.67 & \pm 0.29 & \pm 3.63 \\
\hline \multirow[t]{2}{*}{ Albumin (U) } & $60.77^{\mathrm{aA}}$ & $51.62^{\mathrm{bB}}$ & $58.76^{\mathrm{A}}$ & $49.93^{\mathrm{B}}$ & $65.77^{\mathrm{bc}}$ & 79.25 & $67.19^{C}$ & $94.04^{\mathrm{b}}$ \\
\hline & \pm 1.34 & \pm 1.14 & \pm 0.91 & \pm 0.78 & \pm 1.43 & \pm 0.42 & \pm 0.74 & \pm 4.84 \\
\hline \multirow[t]{2}{*}{ Albumin $(\mathrm{H})$} & $77.31^{\mathrm{b}}$ & $65.67^{\mathrm{aA}}$ & $83.66^{\mathrm{b}}$ & $71.08^{\mathrm{bB}}$ & $62.44^{\mathrm{bA}}$ & 88.75 & $70.52^{\mathrm{aB}}$ & $98.54^{\mathrm{bc}}$ \\
\hline & \pm 0.71 & \pm 0.60 & \pm 1.38 & \pm 1.17 & \pm 4.25 & \pm 0.33 & \pm 0.29 & \pm 5.34 \\
\hline \multirow[t]{2}{*}{ Total globulin (U) } & $72.98^{\mathrm{c}}$ & $62.96^{c}$ & 66.27 & 57.95 & $86.37^{c}$ & $93.76^{\mathrm{aA}}$ & 80.75 & $92.23^{\mathrm{bA}}$ \\
\hline & \pm 2.02 & \pm 1.77 & \pm 0.46 & \pm 0.40 & \pm 3.75 & \pm 2.63 & \pm 0.52 & \pm 2.61 \\
\hline \multirow[t]{2}{*}{ Total globulin $(\mathrm{H})$} & $103.79^{\mathrm{A}}$ & $90.75^{\mathrm{B}}$ & $100.67^{\mathrm{CA}}$ & $88.03^{\mathrm{cB}}$ & $86.41^{\mathrm{cB}}$ & $103.02^{\mathrm{bA}}$ & 82.95 & $100.25^{\mathrm{cA}}$ \\
\hline & \pm 3.10 & \pm 2.71 & \pm 2.83 & \pm 2.48 & \pm 4.54 & \pm 1.17 & \pm 0.40 & \pm 2.30 \\
\hline \multirow[t]{2}{*}{ Major globulin $(\mathrm{H})$} & $93.25^{\mathrm{dA}}$ & $81.29^{\mathrm{dBC}}$ & $99.50^{\mathrm{CAD}}$ & $86.74^{\mathrm{c}}$ & $81.69^{\mathrm{B}}$ & $103.79^{\mathrm{bD}}$ & $77.12^{\mathrm{bC}}$ & $100.29^{\mathrm{cD}}$ \\
\hline & \pm 5.93 & \pm 5.17 & \pm 5.17 & \pm 4.51 & \pm 0.92 & \pm 0.97 & \pm 0.11 & \pm 2.40 \\
\hline \multirow[t]{2}{*}{ Glutelin (H) } & $55.40^{\mathrm{aA}}$ & $47.80^{\mathrm{bA}}$ & $79.56^{\mathrm{abBCD}}$ & $68.66^{\mathrm{aB}}$ & $68.26^{\mathrm{abB}}$ & 97.06 & $76.35^{\mathrm{bc}}$ & $82.85^{\mathrm{aD}}$ \\
\hline & \pm 5.81 & \pm 5.02 & \pm 9.62 & \pm 8.30 & \pm 3.90 & \pm 0.24 & \pm 0.92 & \pm 2.13 \\
\hline
\end{tabular}

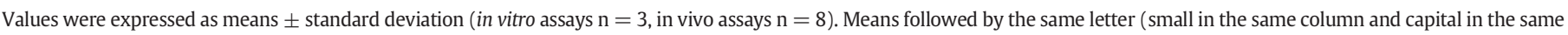
line) indicate no significant difference between samples $(p<0.0500)$.

a $\mathrm{U}=$ Unheated sample, $\mathrm{H}=$ heated sample. The heated samples were autoclaving at $121{ }^{\circ} \mathrm{C} / 15 \mathrm{~min}$.

b ppOPA, ppTNBS, ppKj, pPOPAc and ppTNBSc: pepsin/pancreatin hydrolysis method (Akeson \& Stahman, 1964) using o-phthaldialdehyde $\alpha$-amino group detection (OPA),

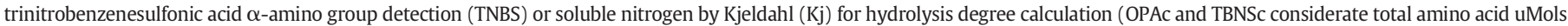

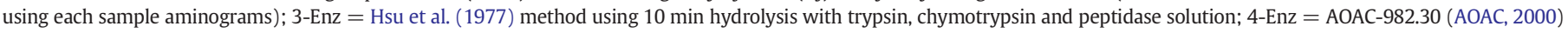
method using 10 min hydrolysis with trypsin, chymotrypsin and peptidase solution, plus additional 10 min using pronase, as described in Materials and methods section.

c $\mathrm{TD}=$ rats fecal true digestibility values, as previously reported in Tavano et al. (2008). 
Table 4

Indispensable amino acid compositions ${ }^{\mathrm{a}}$ and scores $^{\mathrm{b}}$ of chickpea proteins.

\begin{tabular}{|c|c|c|c|c|c|c|c|c|c|c|c|c|c|}
\hline \multirow[t]{2}{*}{ Amino acids } & \multirow[t]{2}{*}{ Pattern $^{c}$} & \multicolumn{2}{|l|}{ Flour } & \multicolumn{2}{|c|}{ Albumin } & \multicolumn{2}{|c|}{ Total globulin } & \multicolumn{2}{|c|}{ Major globulin } & \multicolumn{2}{|c|}{ Glutelin } & \multicolumn{2}{|c|}{ Casein } \\
\hline & & $\overline{\mathrm{AA}^{\mathrm{a}}}$ & Score $^{\mathrm{b}}$ & $\overline{\mathrm{AA}^{\mathrm{a}}}$ & $\overline{\text { Score }^{b}}$ & $\overline{\mathrm{AA}^{\mathrm{a}}}$ & $\overline{\text { Score }^{b}}$ & $\overline{\mathrm{AA}^{\mathrm{a}}}$ & Score $^{b}$ & $\overline{\mathrm{AA}^{\mathrm{a}}}$ & $\overline{\text { Score }^{b}}$ & $\overline{\mathrm{AA}^{\mathrm{a}}}$ & Score $^{\mathrm{b}}$ \\
\hline Thr & 27 & 39.3 & 1.00 & 52.1 & 1.00 & 29.5 & 1.00 & 28.8 & 1.00 & 43.5 & 1.00 & 38.0 & 1.00 \\
\hline Val & 42 & 40.6 & 0.97 & 45.5 & 1.00 & 29.5 & 0.70 & 41.5 & 0.98 & 50.5 & 1.00 & 55.0 & 1.00 \\
\hline Met + Cys & 26 & 19.5 & 0.75 & 47.5 & 1.00 & 9.9 & 0.38 & 8.7 & 0.33 & 18.7 & 0.72 & 35.0 & 1.00 \\
\hline Ile & 31 & 38.3 & $\overline{1.00}$ & 42.7 & 1.00 & 40.5 & $\overline{1.00}$ & 40.6 & $\overline{1.00}$ & 45.2 & $\overline{1.00}$ & 44.0 & 1.00 \\
\hline Leu & 63 & 77.3 & 1.00 & 71.8 & 1.00 & 78.1 & 1.00 & 76.0 & 1.00 & 76.8 & 1.00 & 76.0 & 1.00 \\
\hline Tyr + Phe & 46 & 90.0 & 1.00 & 77.1 & 1.00 & 96.4 & 1.00 & 93.2 & 1.00 & 91.8 & 1.00 & 70.0 & 1.00 \\
\hline Trp & 7.4 & 6.2 & 0.84 & 7.0 & 0.94 & 7.8 & 1.00 & 8.0 & 1.00 & 10.9 & 1.00 & 10.0 & 1.00 \\
\hline Lys & 52 & 73.1 & 1.00 & 93.3 & $\overline{1.00}$ & 66.1 & 1.00 & 65.2 & 1.00 & 78.9 & 1.00 & 68.0 & 1.00 \\
\hline His & 18 & 28.6 & 1.00 & 30.2 & 1.00 & 30.8 & 1.00 & 29.7 & 1.00 & 29.9 & 1.00 & 25.0 & 1.00 \\
\hline
\end{tabular}

a $\mathrm{AA}=$ Amino acid composition ( $\mathrm{mg} / 100 \mathrm{mg}$ protein) as previously reported in Tavano et al. (2008).

b Amino Acid Score = amino acid content in test protein/amino acid content of reference pattern. Values underlined represent the first limiting amino acid of the sample.

c Amino acid scoring patterns for 1-2 years children according to $2007 \mathrm{WHO} / \mathrm{FAO} / \mathrm{UNU}$ report (2007).

reference to calculate the individual value of $100 \%$ of amino acids in the samples. These corrections are not common in the in vitro protein digestibility literature, because the necessity of determining the total amino acid makes it difficult to execute and runs counter to one of the justifications for replacement of in vivo by in vitro methods, which is the simplicity. The total $\mu$ mols of amino acids $/ 50 \mathrm{mg}$ proteins was calculated using the individual molecular weight of each amino acid and their individual concentration observed in each sample (Tavano et al., 2008). The following values were achieved: $381.70,388.68,377.64,378.81$, 382.74 and $330.21 \mu \mathrm{mols}$ of amino acids/50 mg proteins for flour, albumin, total globulin, major globulin, glutelin and casein, respectively. It is possible to observe the differences between the corrected (ppOPAc and ppTNBSc) and non-corrected (ppOPA and ppTNBS) values (Table 1), which can expose the variation enclosed in the standardization of the initial amino acid concentration (which assumes $50 \mathrm{mg}$ protein $=$ $442 \mu$ mols amino acids for all samples).

The adoption of the individual amino acid concentration in each sample produced a relative increase in the percentage of hydrolysis values (ppTNBSc and ppOPAc in comparison of ppTNBS and ppOPA), as shown in Table 1 because all results for the total $\mu$ moles of amino acids were lower than those values calculated by the average molecular weight of the amino acids. However, when these percentages are expressed in relation to casein (\%) the proportions are reversed (Table 3 ), and there is a reduction in ppTNBSc and ppOPAc digestibility values compared to ppTNBS and ppOPA. This is because the values by the total number of amino acids of casein suffer the greatest reduction when the aminogram is used (Tables 1 and 3 ).

This correction in the calculations by aminograms, although made to obtain the most accurate results and therefore increase similarity to in vivo condition, caused no major changes in the correlations of these methods with the results generated by testing with animals (Table 2). In fact, none of the correlations established between the digestibility in vitro and in vivo were significant (at $p<0.0500$ ). The only significant correlations found were between some in vitro methods and most of these were moderate correlations (Table 2).

Panasiuk, Amarowicz, Kostyra, and Sijtsma (1998) found a correlation coefficient of 0.964 for the TNBS and OPA methods for raw pea protein samples after hydrolysis. In this study, the correlation between ppOPA and ppTNBS was $0.8172(p=0.0133)$, and the correlation between ppOPAc and ppTNBSc was $0.8289(p=0.0109)$, as shown in

Table 5

Protein digestibility-corrected amino acid score (PDCAAS) of chickpea proteins and casein calculated using different in vitro and in vivo protein digestibility assays.

\begin{tabular}{|c|c|c|c|c|c|c|c|c|}
\hline \multirow[t]{3}{*}{ Samples $^{\mathrm{a}}$} & \multicolumn{8}{|l|}{ PDCAAS } \\
\hline & \multicolumn{7}{|c|}{ First limiting amino acid score $(A A S) \times$ in vitro digestibilities ${ }^{\mathrm{b}}$} & \multirow[t]{2}{*}{$\mathrm{AAS} \times \mathrm{TD}^{\mathrm{c}}$} \\
\hline & ppOPA & pPOPAc & ppTNBS & ppTNBSc & $\mathrm{ppKj}$ & 3-Enz & 4-Enz & \\
\hline \multirow[t]{2}{*}{ Casein } & $65.99^{A}$ & $88.41^{\mathrm{aBC}}$ & 47.04 & $63.02^{\mathrm{A}}$ & $87.09^{\mathrm{aBC}}$ & $86.05^{\mathrm{B}}$ & 107.75 & $91.59^{\mathrm{aC}}$ \\
\hline & \pm 2.90 & \pm 3.88 & \pm 1.17 & \pm 1.57 & \pm 4.09 & \pm 0.55 & \pm 1.84 & \pm 1.67 \\
\hline \multirow[t]{2}{*}{ Flour (U) } & $31.65^{\mathrm{A}}$ & 36.68 & $26.05^{\mathrm{a}}$ & $30.19^{\mathrm{abA}}$ & $48.37^{\mathrm{ab}}$ & 53.24 & $60.40^{\mathrm{B}}$ & $58.82^{\mathrm{bB}}$ \\
\hline & \pm 0.89 & \pm 1.03 & \pm 0.74 & \pm 0.86 & \pm 2.56 & \pm 0.21 & \pm 0.45 & \pm 5.91 \\
\hline \multirow[t]{2}{*}{ Flour $(\mathrm{H})$} & $39.75^{\mathrm{aA}}$ & $46.07^{\mathrm{aAB}}$ & $28.54^{\mathrm{a}}$ & $33.08^{\mathrm{a}}$ & $47.69^{\mathrm{abB}}$ & $60.20^{\mathrm{aC}}$ & $61.52^{\mathrm{C}}$ & $59.06^{\mathrm{bC}}$ \\
\hline & \pm 3.57 & \pm 4.14 & \pm 1.60 & \pm 1.85 & \pm 2.38 & \pm 0.43 & \pm 0.25 & \pm 2.56 \\
\hline \multirow[t]{2}{*}{ Albumin (U) } & $37.69^{\mathrm{a}}$ & $42.90^{\mathrm{a}}$ & $25.98^{\mathrm{a}}$ & $29.57^{b}$ & $53.84^{\mathrm{c}}$ & 64.10 & 73.40 & $83.43^{c}$ \\
\hline & \pm 0.83 & \pm 0.95 & \pm 0.40 & \pm 0.46 & \pm 1.17 & \pm 0.34 & \pm 0.80 & \pm 4.29 \\
\hline \multirow[t]{2}{*}{ Albumin $(\mathrm{H})$} & $47.95^{\mathrm{A}}$ & $54.58^{\mathrm{B}}$ & 37.00 & 42.11 & $51.12^{\mathrm{bcAB}}$ & 71.79 & 77.04 & $87.42^{\mathrm{ac}}$ \\
\hline & \pm 0.44 & \pm 0.50 & \pm 0.61 & \pm 0.70 & \pm 3.48 & \pm 0.27 & \pm 0.32 & \pm 4.74 \\
\hline \multirow{2}{*}{ Total globulin (U) } & 18.05 & $21.15^{b}$ & 11.84 & 13.88 & $28.58^{\mathrm{dA}}$ & $30.66^{\mathrm{bA}}$ & 35.66 & $33.08^{d}$ \\
\hline & \pm 0.50 & \pm 0.59 & \pm 0.09 & \pm 0.02 & \pm 1.24 & \pm 0.84 & \pm 0.23 & \pm 0.93 \\
\hline \multirow[t]{2}{*}{ Total globulin $(\mathrm{H})$} & $26.03^{\mathrm{bA}}$ & $30.49^{\mathrm{cB}}$ & 18.00 & 21.08 & $28.60^{\mathrm{dAB}}$ & 33.69 & $36.63^{C}$ & $35.95^{\mathrm{C}}$ \\
\hline & \pm 0.77 & \pm 0.91 & \pm 0.50 & \pm 0.59 & \pm 1.50 & \pm 0.38 & \pm 0.18 & \pm 0.82 \\
\hline \multirow[t]{2}{*}{ Major globulin $(\mathrm{H})$} & $20.30^{A}$ & $23.71^{\mathrm{bB}}$ & 15.44 & $18.04^{\mathrm{A}}$ & $23.32^{\mathrm{B}}$ & $29.47^{\mathrm{bCD}}$ & $29.58^{\mathrm{C}}$ & $31.23^{\mathrm{dD}}$ \\
\hline & \pm 1.29 & \pm 1.51 & \pm 0.80 & \pm 0.94 & \pm 0.26 & \pm 0.28 & \pm 0.05 & \pm 0.75 \\
\hline \multirow[t]{2}{*}{ Glutelin (H) } & $26.32^{\mathrm{bA}}$ & $30.43^{\mathrm{cA}}$ & $26.95^{\mathrm{aA}}$ & $31.15^{\mathrm{abA}}$ & $42.80^{\mathrm{a}}$ & $60.13^{a}$ & 63.88 & $56.30^{\mathrm{b}}$ \\
\hline & \pm 2.76 & \pm 3.19 & \pm 3.26 & \pm 3.76 & \pm 2.45 & \pm 0.15 & \pm 0.77 & \pm 1.45 \\
\hline
\end{tabular}

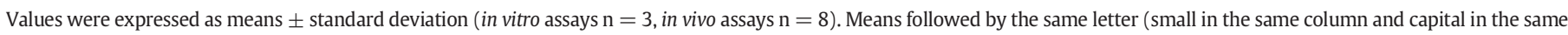
line) indicate no significant difference between samples $(p<0.0500)$.

${ }^{a} \mathrm{U}=$ Unheated sample, $\mathrm{H}=$ heated sample. The heated samples were autoclaving at $121{ }^{\circ} \mathrm{C} / 15 \mathrm{~min}$.

b pPOPA, ppTNBS, ppKj, ppOPAc and ppTNBSc: pepsin/pancreatin hydrolysis method (Akeson \& Stahman, 1964) using o-phthaldialdehyde $\alpha$-amino group detection (OPA),

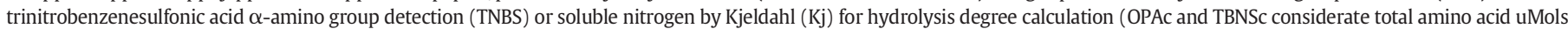

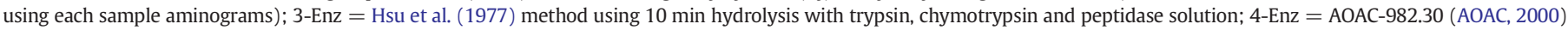
method using 10 min hydrolysis with trypsin, chymotrypsin and peptidase solution, plus additional 10 min using pronase, as described in Materials and methods section.

c $\mathrm{TD}=$ rats fecal true digestibility values, as previously reported in Tavano et al. (2008). 
Table 6

Correlation coefficients between in vitro/in vivo chickpea protein digestibility corrected amino acid score values.

\begin{tabular}{ll}
\hline Correlated methods & Correlation coefficients $(\mathrm{r})^{\mathrm{a}}$ \\
\hline TD/ppOPA & $0.9007(p=0.0279)^{*}$ \\
TD/ppOPAc & $0.8916(p=0.0319)^{*}$ \\
TD/ppTNBS & $0.8852(p=0.0009)^{*}$ \\
TD/ppTNBSc & $0.8755(p=0.0013)^{*}$ \\
TD/ppKj & $0.9316(p=0.0247)^{*}$ \\
TD/3-Enz & $0.9442(p=0.0135)^{*}$ \\
TD/4-Enz & $0.9649(p=0.0104)^{*}$ \\
\hline
\end{tabular}

a Only chickpea values were considered.

* Marked correlations (r) are significant at $p<0.0500$.

Table 2. The ppOPA method showed the greatest ability to differentiate between raw and heated samples, followed by ppTNBS, 3-Enz and 4Enz (Table 1).

Although the 3-Enz and 4-Enz methods were able to distinguish the crude from heated samples, the percentage increase of digestibility after heat treatment expressed by these two methods is, in most cases, much lower than that demonstrated by pepsin-pancreatin. For albumin samples, for example, ppOPA and ppTNBS showed increases of approximately $27 \%$ and $42 \%$, respectively, whereas 3-Enz and 4-Enz found increases of approximately 12 and 5\% (Table 1). The same was found for total globulin sample, where pPOPA and ppTNBS showed increases of approximately $44 \%$ and 52\% and 3-Enz and 4-Enz showed increases of approximately 10 and 3\%, respectively.

These two last methods, besides using a different hydrolysis degree detection principle, also use a much larger amount of enzymes, and their ratio is approximately 1:10 enzyme:substrate, while for pepsinpancreatin this ratio is between 1:50 (pepsin) and 1:25 (pancreatin). That may help explain the higher percentage of hydrolysis observed for these methods. The 4-Enz method in particular makes use of an additional hydrolysis step with pronase. Pronase is a commercial preparation containing several proteases from Streptomyces griseus (Trop \& Birk, 1970), usually applied when a high degree of hydrolysis is desired.
Values for the 4-Enz method are in fact among the highest results for digestibility, including the extrapolation of casein dates (presenting $107.75 \%$ ), suggesting a possible overestimation when this method is used. Another important observation regarding these two methods is that the entire hydrolysate is used for computing the amount of hydrolysis, while in the pepsin-pancreatin method only the supernatant after TCA precipitation is used.

According to Wolzak, Bressani, and Brenes (1981), different enzymatic and chemical methods were not equally sensitive to certain physical and chemical characteristics of food samples, such as presence of anti-nutritional and cell wall structures, which contributes to the difficulty of establishing a single protocol that is applicable to different samples and showing a close relationship with in vivo phenomena. In the physiological process of digestion, other processes and enzymes could contribute indirectly to protein digestion, as they help with the destruction of food matrix and thus allow improved access of proteases. These variables are generally not computed in vitro, as they usually only consider isolated proteases.

With regard to antinutritional compounds, especially protease inhibitors, in vitro assays may react to their presence in different ways than seen in for in vivo digestion. Although most in vitro assays have pointed to an improvement of digestibility of flour, albumin and total globulin samples after heating, the TD data (Tavano et al., 2008) (true digestibility) indicated that this is not always detectable in vivo (Table 1 ). Using this method, flour and albumin sample digestibilities were not significantly increased after heating. It is interesting to note that these fractions have higher values of the trypsin inhibitor unit (TIU), according to previously observed data (38.72, 2.31, 239.20 and 5.47 TIU/ mg protein, respectively for unheated and heated flour, and unheated and heated albumin) (Tavano et al., 2008). A significant improvement in their digestibilities would be expected, therefore, after heat treatment, but this was not observed for in vivo testing. At first sight, this indicates that these in vivo tests were not greatly influenced by the presence of these inhibitory components. This could be due to an adaptive effect, demonstrated by the changes observed in the pancreas of rats fed the same samples of unheated flour and albumin, as shown in previously published studies (Tavano et al., 2005). These data clearly

Table 7

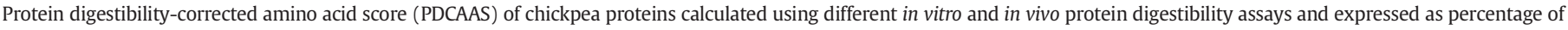
casein value (100\%).

\begin{tabular}{|c|c|c|c|c|c|c|c|c|}
\hline \multirow[t]{2}{*}{ Samples $^{a}$} & \multicolumn{8}{|c|}{ PDCAAS (\% of casein values) ${ }^{\mathrm{b}}$} \\
\hline & ppOPA & ppOPAc & ppTNBS & ppTNBSc & $\mathrm{ppKj}$ & 3-Enz & 4-Enz & $\mathrm{TD}^{\mathrm{c}}$ \\
\hline Casein & 100 & 100 & 100 & 100 & 100 & 100 & 100 & 100 \\
\hline \multirow{2}{*}{ Flour (U) } & $47.96^{\mathrm{A}}$ & 41.49 & $55.37^{\mathrm{aB}}$ & $47.90^{\mathrm{abA}}$ & $55.54^{\mathrm{acB}}$ & $61.87^{\mathrm{C}}$ & $56.05^{\mathrm{B}}$ & $61 .^{21 \mathrm{aBC}}$ \\
\hline & \pm 1.35 & \pm 1.16 & \pm 1.26 & \pm 1.36 & \pm 2.98 & \pm 0.24 & \pm 0.41 & \pm 6.15 \\
\hline \multirow[t]{2}{*}{ Flour $(\mathrm{H})$} & $60.24^{\mathrm{aABC}}$ & $52.10^{\mathrm{aABC}}$ & $60.67^{\mathrm{aA}}$ & $52.48^{\mathrm{aB}}$ & $54.76^{\mathrm{acAB}}$ & $69.95^{\mathrm{a}}$ & $57.10^{\mathrm{A}}$ & $61.47^{\mathrm{aC}}$ \\
\hline & \pm 5.40 & \pm 4.98 & \pm 3.40 & \pm 2.93 & \pm 2.73 & \pm 0.50 & \pm 0.23 & \pm 2.67 \\
\hline \multirow[t]{2}{*}{ Albumin (U) } & $57.12^{\mathrm{aA}}$ & $48.53^{\mathrm{aB}}$ & $55.23^{\mathrm{aA}}$ & $46.93^{\mathrm{bB}}$ & $61.82^{\mathrm{b}}$ & 74.49 & 68.12 & $86.84^{\mathrm{b}}$ \\
\hline & \pm 1.26 & \pm 1.07 & \pm 0.85 & \pm 0.73 & \pm 1.34 & \pm 0.39 & \pm 0.74 & \pm 4.46 \\
\hline \multirow[t]{2}{*}{ Albumin $(\mathrm{H})$} & $72.66^{\mathrm{A}}$ & $61.73^{\mathrm{B}}$ & 78.65 & 66.82 & $58.69^{\mathrm{bcB}}$ & 83.43 & $71.50^{\mathrm{A}}$ & $90.99^{\mathrm{b}}$ \\
\hline & \pm 0.67 & \pm 0.56 & \pm 1.29 & \pm 1.11 & \pm 4.00 & \pm 0.31 & \pm 0.30 & \pm 4.93 \\
\hline \multirow[t]{2}{*}{ Total globulin (U) } & 27.36 & $23.92^{\mathrm{b}}$ & 25.18 & 22.02 & $32.82^{\mathrm{dA}}$ & $35.63^{b}$ & $33.09^{\mathrm{A}}$ & $34.43^{c}$ \\
\hline & \pm 0.76 & \pm 0.67 & \pm 0.19 & \pm 0.01 & \pm 1.42 & \pm 0.97 & \pm 0.21 & \pm 1.04 \\
\hline \multirow[t]{2}{*}{ Total globulin $(\mathrm{H})$} & $39.44^{\mathrm{bA}}$ & $34.48^{\mathrm{cBC}}$ & $38.26^{\mathrm{AB}}$ & $33.45^{\mathrm{BC}}$ & $32.84^{\mathrm{dC}}$ & $39.15^{\mathrm{A}}$ & $34.00^{\mathrm{BC}}$ & $37.42^{\mathrm{AB}}$ \\
\hline & \pm 4.13 & \pm 3.61 & \pm 4.62 & \pm 4.06 & \pm 1.88 & \pm 0.09 & \pm 0.41 & \pm 0.85 \\
\hline \multirow[t]{2}{*}{ Major globulin $(\mathrm{H})$} & $30.77^{\mathrm{AB}}$ & $26.82^{\mathrm{bAC}}$ & $32.83^{\mathrm{B}}$ & $28.63^{\mathrm{AC}}$ & $26.78^{C}$ & $34.25^{\mathrm{b}}$ & $27.45^{\mathrm{C}}$ & $32.51^{\mathrm{cB}}$ \\
\hline & \pm 1.96 & \pm 1.68 & \pm 1.70 & \pm 1.51 & \pm 0.30 & \pm 0.33 & \pm 0.04 & \pm 0.78 \\
\hline \multirow[t]{2}{*}{ Glutelin $(\mathrm{H})$} & $39.89^{\mathrm{bAB}}$ & $34.42^{\mathrm{CA}}$ & $57.29^{\mathrm{aCD}}$ & $49.44^{\mathrm{abBC}}$ & $49.15^{\mathrm{aC}}$ & $69.88^{\mathrm{a}}$ & $59.28^{\mathrm{D}}$ & $58.59^{\mathrm{aD}}$ \\
\hline & \pm 4.18 & \pm 3.61 & \pm 6.91 & \pm 5.99 & \pm 2.81 & \pm 0.17 & \pm 0.71 & \pm 1.51 \\
\hline
\end{tabular}

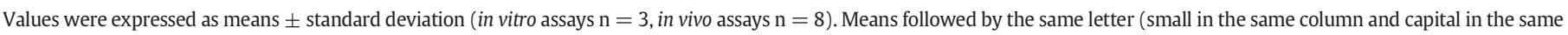
line) indicate no significant difference between samples $(p<0.0500)$.

${ }^{\text {a } ~} \mathrm{U}=$ Unheated sample, $\mathrm{H}=$ heated sample. The heated samples were autoclaving at $121{ }^{\circ} \mathrm{C} / 15 \mathrm{~min}$.

b ppOPA, ppTNBS, ppKj, pPOPAc and ppTNBSc: pepsin/pancreatin hydrolysis method (Akeson \& Stahman, 1964) using o-phthaldialdehyde $\alpha$-amino group detection (OPA),

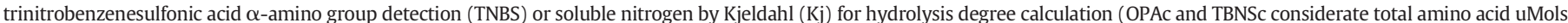

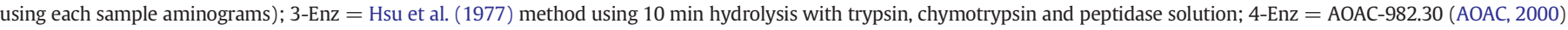
method using 10 min hydrolysis with trypsin, chymotrypsin and peptidase solution, plus additional 10 min using pronase, as described in Materials and methods section.

c $\mathrm{TD}=$ rats fecal true digestibility values, as previously reported in Tavano et al. (2008). 
showed that animals suffered hypertrophy of this organ ( $42 \%$ of pancreatic increase in animals fed with unheated flour and $45.5 \%$ for rats fed with unheated albumin after 14 days, while the other groups showed no changes). This suggests that the results found for protein digestibility could reflect a physiological adaptation of these animals, which could generate a compensatory effect enzyme production to overcome differences between heated and unheated samples. In those in vitro assays that utilize high concentrations of enzymes (3-Enz and 4-Enz), especially trypsin and chymotrypsin, this type of compensating effect might also be occurring.

On the other hand, digestibility increases caused by heat treatment, as observed for total sample globulin (TIU low levels) (Tavano et al., 2008), may be more reflective of conformational changes than thermolabile antinutritionals.

It is very difficult to isolate the main factor responsible for the effect of heating on proteins, as many effects are likely taking place. In general, in vitro assays appear to be more sensitive to variations in the levels of protease inhibitors, though at different proportions. Considering that this test aims to mimic what would occur in vivo, then, could be considered that a lower sensitivity of in vitro methods to these protease inhibitors could be more interesting. However, if the goal is to understand differentiation between samples as a result of heat treatment, then in vitro tests that are more sensitive to all factors would be most relevant.

Some authors express in vitro digestibility data as direct percentages of a standard protein result, such as casein. This form of expression may reduce differentiation in the data between the different methods employed, allowing comparison of data generated by the various methods. Table 3 shows digestibility data in relation to casein (Casein value $=100 \%$ ). Although many results were similar, there is still a wide range of results for the same sample. These observations emphasize the need for care when comparisons between published studies are performed; the same sample assessed using different methods can produce different conclusions. Therefore, it is recommended to compare data produced using the same method. Urbano et al. (2005) also found different values for chickpea samples when two in vitro (Hsu et al., 1977; and Akeson \& Stahman, 1964, methods) and one in vivo methods were used.

Table 4 shows aminograms and amino acid scores for each sample, calculated according to WHO/FAO/UNU (2007) patterns for 1- to 2year old children. Considering the results of in vitro assays for the calculation of PDCAAS (Table 5), even with the difficulties in establishing correlations between digestibility methods (Table 2), strong correlations were observed (at $p<0.0500$ ) between PDCAAS results produced by in vitro and in vivo digestibility results (Table 6).

Although we observe variation between the values obtained using each method (Table 5) for a given sample, the use of in vitro methods for calculating PDCAAS may be promising. In addition to the strong correlations found (Table 6), when the results were expressed as \% casein (Table 7), the percentage values were much closer to those obtained with the use of in vivo methods (PDCAAS-TD), and several in vitro results were not significantly different from the PDCAAS data calculated using TD (Table 7). For example, among the eight PDCAAS-TNBS results, four of them significantly coincided with PDCAAS-TD. In addition, all trials using in vitro data were able to point to the sample of heated albumin as the highest values, and they were also able to point to globulins as the worst quality proteins, which coincides with PDCAAS-TD results. In fact, PDCAAS-ppKJ, PDCAAS-3-Enz and PDCAAS-4-Enz methods presented the highest correlations with in vivo method, $\mathrm{r}=0.9316,0.9442$ and $0.9649(p<0.0500)$, respectively (as shown in Table 6).

\section{Conclusions}

While there have been a great difficulty in establishing a correlation between the results of protein digestibility generated by in vitro methods, the data generated in this study suggest that in vitro digestibility results can be apply to calculate the PDCAAS with prospects of good correlations with results generated by in vivo tests. The lower results found for correlations between PDCAAS-in vivo and PDCAAS-in vitro were found when the PDCAAS-TNBSc was used $(\mathrm{R}=0.8755$, and $p=$ $0.0013)$. The highest correlation was $r=0.9649(p=0.0104)$, considering PDCAAS-TD X PDCAAS-4-Enz. Considering the three in vitro methods that generated the highest correlation, perhaps 3-Enz method could be considered the highlight, in the conditions of this work, presenting as less labor and less time consuming. Moreover, the application of in vitro methods allowed for differentiation between samples of chickpea protein, including showing sensitivity to differentiate samples after heat treatment. In addition, the tests showed other important advantages over in vivo assays such as simplicity, convenience, speed, lower cost and specially the reduction in animal usage. Thus, the use of in vitro methods for this digestibility analysis deserves further study and discussion, with a special focus on seeking the standardization of one method as the most appropriate. Larger studies will be important as they can consider greater numbers and types of proteins, including different compositions of samples with variations in presence of antinutritional and other components that could interfere with protein digestibility. The choice of a method as a reference will reduce the present difficulties in comparing data, as this study demonstrated that the same sample may display different results when different methods are applied.

\section{References}

Akeson, W. R., \& Stahman, M. A. A. (1964). Pepsin-pancreatin digest index of protein quality evaluation. The Journal of Nutrition, 83, 257-261.

Association of Official Analytical Chemists (1990). Official methods of analysis. Association of Official Analytical Chemists: Washington D. C.

Association of Official Analytical Chemists (2000). Official methods of analysis of Association of Official Analytical Chemists: Gaithersburg, MD. Official method 982. (pp. 30), 30.

Boye, J., Wijesinha-Bettoni, R., \& Burlingame, B. (2012). Protein quality evaluation twenty years after the introduction of the protein digestibility corrected amino acid score method. The British Journal of Nutrition, 108, S183-S211.

Church, F. C. C., Swaisgood, H. E., Porter, D. H., \& Catignani, G. L. (1983). Spectrophotometric assay using o-phthaldialdehyde for determination of proteolysis in milk and isolated milk proteins. Journal of Dairy Science, 66, 1219-1227.

Fields, R. (1972). The rapid determination of amino groups with TNBS. Methods in Enzymology, 25, 464-468.

Hsu, H. W., Vavak, D. L., Satterlee, L. D., \& Miller, G. A. (1977). A multienzyme technique for estimating protein digestibility. Journal of Food Science, 42, 1269-1273.

Jahan-Mihan, A., Luhovyy, B. L., El Khoury, D., \& Anderson, G. H. (2011). Dietary proteins as determinants of metabolic and physiologic functions of the gastrointestinal tract. Nutrients, 3, 574-603.

Leser, S. (2013). The 2013 FAO report on dietary protein quality evaluation in human nutrition: Recommendations and implications. Nutrition Bulletin, 38, 421-428.

McDonough, F. E., Steinke, F. H., Eggum, B. O., Bressani, R., Huth, P. J., Barbeau, W. E., .. Phillips, J. G. (1990). In vivo rat assay for true protein digestibility: Collaborative study. Journal of Association of Analytical Chemistry, 73, 801-805.

Panasiuk, R., Amarowicz, O. R., Kostyra, H., \& Sijtsma, L. (1998). Determination of a-amino nitrogen in pea protein hydrolysates: A comparison of three analytical methods. Food Chemistry, 62, 363-367.

Pappenheimer, J. R., Dahl, C. E., Karnovsky, M. L., \& Maggio, J. E. (1994). Intestinal absorption and excretion of octapeptides composed of D amino acidsProceedings of the National Academy of Sciences of the United States of America91. (pp. 1942-1945).

Sarwar, G., \& Mcdonough, F. E. (1990). Evaluation of protein digestibility corrected amino acid score method for assessing protein quality of foods. Journal of the Association of Official Analytical Chemists, 73, 347-356.

Schaafsma, G. (2012). Advantages and limitations of the protein digestibility-corrected amino acid score (PDCAAS) as a method for evaluating protein quality in human diets. The British Journal of Nutrition, 108, S333-S336.

Spadaro, A. C. C., Draghetta, W., Del Lama, S. N., Camargo, A. C. M., \& Greene, L. T. (1979). A convenient manual trinitrobenzenesulfonic acid method for monitoring amino acids and peptides in chromatographic column effluents. Analytical Biochemistry, 96, 317-321.

Statistica 8.0 (2007). Statistics computer program for Windows. Vol. 1, Tulsa: StatSoft Inc Software.

Tavano, O. L., Silva Junior, S. I., Demonte, A., \& Neves, V. A. (2005). Pancreatic hypertrophy in rats caused by chickpea (Cicer arietinum L.) protein intake. Alimentos e Nutrição, 16 5-10.

Tavano, O. L., Silva Junior, S. I., Demonte, A., \& Neves, V. A. (2008). Nutritional responses of rats to diets based on chickpea (Cicer arietinum L.) seed meal or its protein fractions. Journal of Agricultural and Food Chemistry, 56, 11006-11010.

Trop, M., \& Birk, Y. (1970). The specificity of proteinases from Streptomyces griseus (Pronase). Biochemical Journal, 116, 19-25. 
Urbano, G., López-Jurado, M., Frejnagel, S., Gómez-Villalva, E., Porres, J. M., Frías, J., ... Aranda, P. (2005). Nutritional assessment of raw and germinated pea (Pisum sativum L.) protein and carbohydrate by in vitro and in vivo techniques. Nutrition, 21, 230-239.

WHO/FAO/UNU Expert Consultation (2007). Protein and amino acid requirements in human nutrition. WHO technical reports series no. 935.. Geneva: World Health Organization.
Wolzak, A., Bressani, R., \& Brenes, R. G. (1981). A comparison of in vivo and in vitro estimates of protein digestibility of native and thermally processed vegetable proteins. Plant Foods for Human Nutrition, 31, 31-43.

Yvon, M., Chabanet, C., \& Pélissier, J. P. (1989). Solubility of peptides in tricloroacetic acid (TCA) solutions. Hypotesis on the precipitation mechanism. International Journal of Peptide and Protein Research, 34, 166-176. 